\title{
A Case of Choanal Polyp Originated from the Inferior Turbinate
}

\author{
Ju Chang Kang ${ }^{1}$, Kyu Ha Shin ${ }^{1}$, Kye Won Kwon ${ }^{2}$, and Sang Hyeon $\mathrm{Ahn}^{1}{ }^{1}$ \\ ${ }^{1}$ Departments of Otorhinolaryngology-Head and Neck Surgery, ${ }^{2}$ Pathology, Bundang Jesaeng General Hospital, Daejin Medical Center, \\ Seongnam, Korea
}

\author{
하비갑개에서 기원한 후비공 용종 1 예 \\ 강주창 $^{1}$ - 신규하 ${ }^{1} \cdot$ 권계원 $^{2} \cdot$ 안상현 $^{1}$

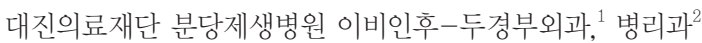

\author{
Received June 29, 2020 \\ Revised September 2, 2020 \\ Accepted September 7, 2020 \\ Address for correspondence \\ Sang Hyeon Ahn, MD \\ Department of Otorhinolaryngology- \\ Head and Neck Surgery, \\ Bundang Jesaeng General Hospital, \\ Daejin Medical Center, \\ 20 Seohyeon-ro 180beon-gil, \\ Bundang-gu, Seongnam 13590, \\ Korea \\ Tel $+82-31-779-0258$ \\ Fax $+82-31-779-0265$ \\ E-mail dolyunnim21@hanmail.net
}

The choanal polyp, originating from inferior turbinate, is known to be extremely rare. We report a case of a 65-year-old woman who was treated for choanal polyp originating from inferior turbinate. She had felt left nasal obstruction for two weeks. In the endoscopic examination, polypoid tissue covered with the mucopurulent discharge was observed filling the left inferior meatus. An ovoid homogenous enhancing lesion in the left posterior nasal cavity around the inferior turbinate was observed on CT and MRI. Endoscopic mass excision with partial inferior turbinectomy was performed under general anesthesia. The pedicle of the polyp was observed on the posterior side of the inferior turbinate. Complete resection including the mucosa around the pedicle of the choanal polyp was performed. The patient was followed up for seven months without any recurrence or complications.

Korean J Otorhinolaryngol-Head Neck Surg 2020;63(12):611-4

Key Words Choanal polyp · Endoscopic surgery $\cdot$ Inferior turbinate $\cdot$ Nasal cavity · Paranasal sinus.

\section{서 론}

후비공 비용(choanal polyp)은 비부비동의 점막에서 기원 하여 후비공까지 진행하는 단발성의 양성 종양으로 상악동, 접형동, 사골동에서 발생하고 그 중 상악동 후비공 비용(antrochoanal polyp)이 가장 흔하게 발생하는 것으로 알려져 있 다. ${ }^{1,2)}$ 또한 전두동, 비중격, 상비갑개, 중비갑개, 하비갑개, 사 상판에서도 발생하는 것으로 보고되었으나 이는 매우 드문 것으로 알려져 있다. ${ }^{1-3)}$ 특히, 하비갑개에서 기시하는 후비공 비용은 Gordts와 Clement가 1997년 최초로 보고한 이후로 6개의 증례만이 보고되었으며 ${ }^{2,4)}$ 국내에서는 아직까지 보고

This is an Open Access article distributed under the terms of the Creative Commons Attribution Non-Commercial License (https://creativecommons.org/licenses/by-nc/4.0) which permits unrestricted non-commercial use, distribution, and reproduction in any medium, provided the original work is properly cited.
된 바가 없다. 본 증례는 좌측 코막힘을 주소로 내원하여 하 비갑개에서 기원한 후비공 비용을 진단받고 완치한 65세 여 자 환자에 대한 보고와 문헌 고찰을 하고자 한다.

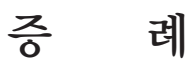

65세 여자 환자가 2주 전부터 시작된 좌측 코막힘과 화농 성 비루를 주소로 내원하였다. 고혈압으로 약물 치료 중이었 으며 그 외 내과적 기저 질환은 없었다. 비내시경 검사에서 화 농성 분비물을 동반한 경계가 불규칙적인 종물이 좌측 하비 도의 후방을 채우며 후비공까지 진행되어 있었고, 종물 주변 으로 하비갑개와 하비도 점막의 비후가 관찰되었다(Fig. 1).

종물을 감별하기 위해 펀치 생검(punch biopsy), 부비동 전 산화단층촬영(computed tomography, CT) 및 자기공명영상 


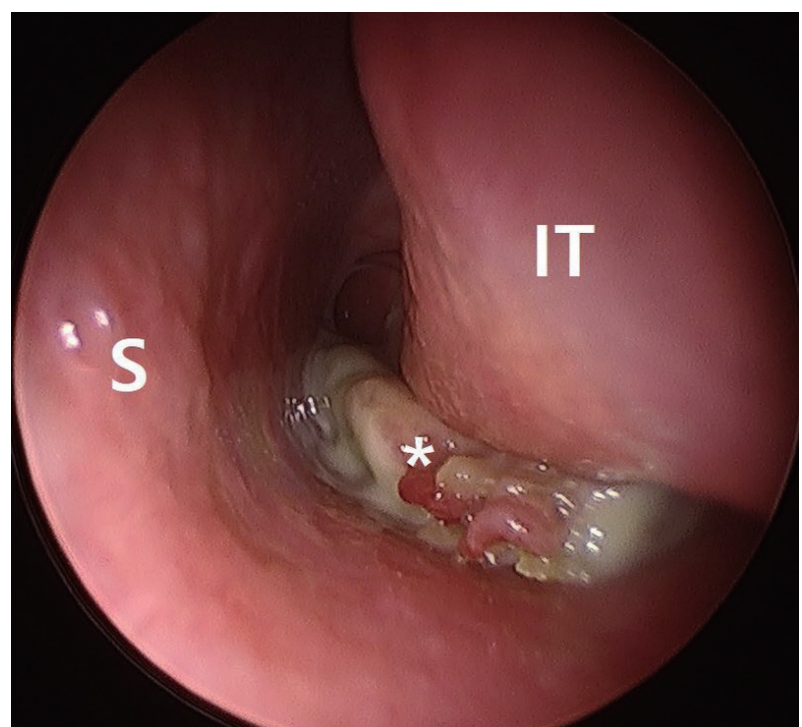

Fig. 1. Preoperative endoscopic findings. A bizarre single polypoid mass $\left(^{*}\right)$ is located between the left inferior turbinate and the basal floor of the nasal cavity. S: septum, IT: inferior turbinate. (magnetic resonance image, MRI)을 시행하였다. 펀치 생검 의 결과는 다수의 급·만성 염증 세포가 존재하는 것으로 보 고되었다. CT 영상에서 좌측 하비도의 점막비후가 관찰되었 으며, 하비도 후방의 기저부에서 연조직 음영이 관찰되는 것 이외 주변의 골결손이나 양측 부비동 및 비강에 특이소견은 없었다(Fig. 2). MRI T2 조영 증강 영상에서는 좌측 하비갑 개 후방에서 시작하여 후비공까지 차지하고 있는 종물이 강 한 신호강도를 보였다(Fig. 3).

종물의 완전한 절제를 위하여 전신마취 후 비내시경을 이 용한 종물 절제술(endoscopic mass excision)을 시행하기로 계획하였다. 하비갑개로 인해 종물의 기시부를 확인하는 데 제 한이 있어, 하비갑개의 후방부 일부분을 절제하였다. 종물은 하비갑개의 후하방에서 기원하는 것을 확인하였고(Fig. 4), sickle knife와 cutting forceps을 가지고 주변 점막을 포함하 여 완전 절제를 시행 후 재발 방지를 위해 종물의 기시부에 전 기 소작을 시행하고 수술을 종료하였다. 종물의 크기는 $2.0 \times$
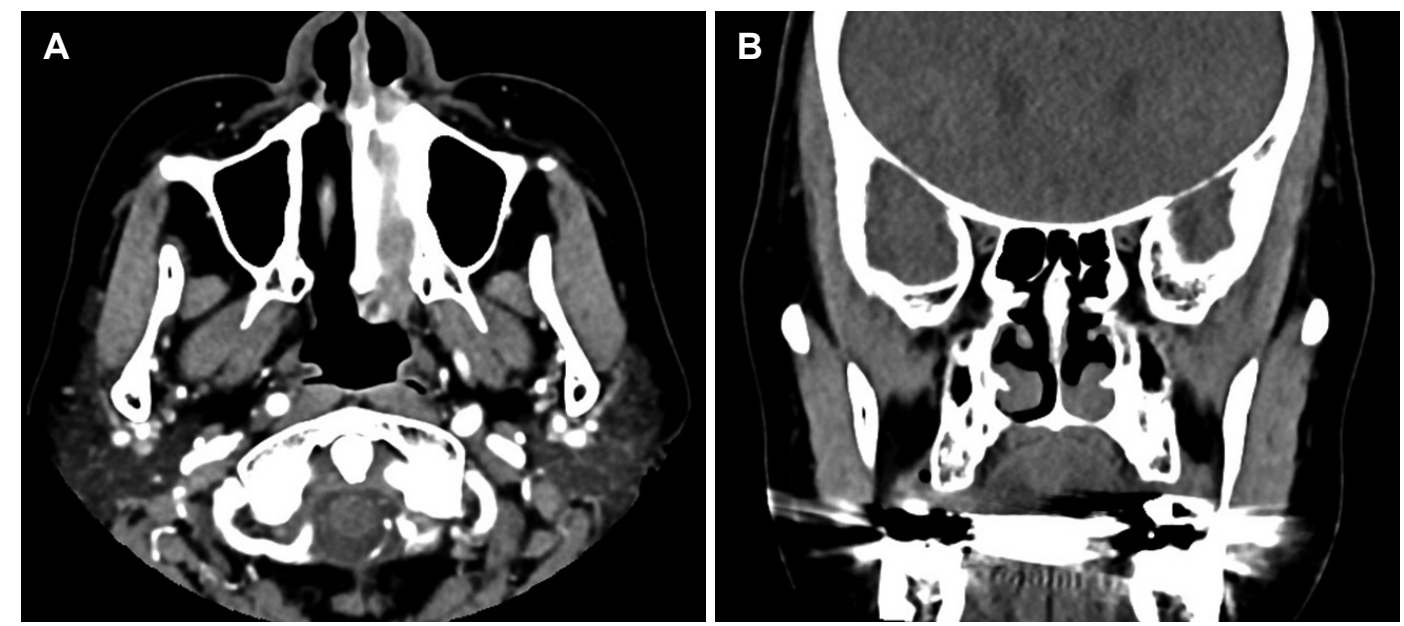

Fig. 2. Preoperative CT findings. Axial (A) and coronal (B) view. CT shows soft tissue density at the basal floor of the nasal cavity. Bone erosion is not observed and paranasal sinus is clear.
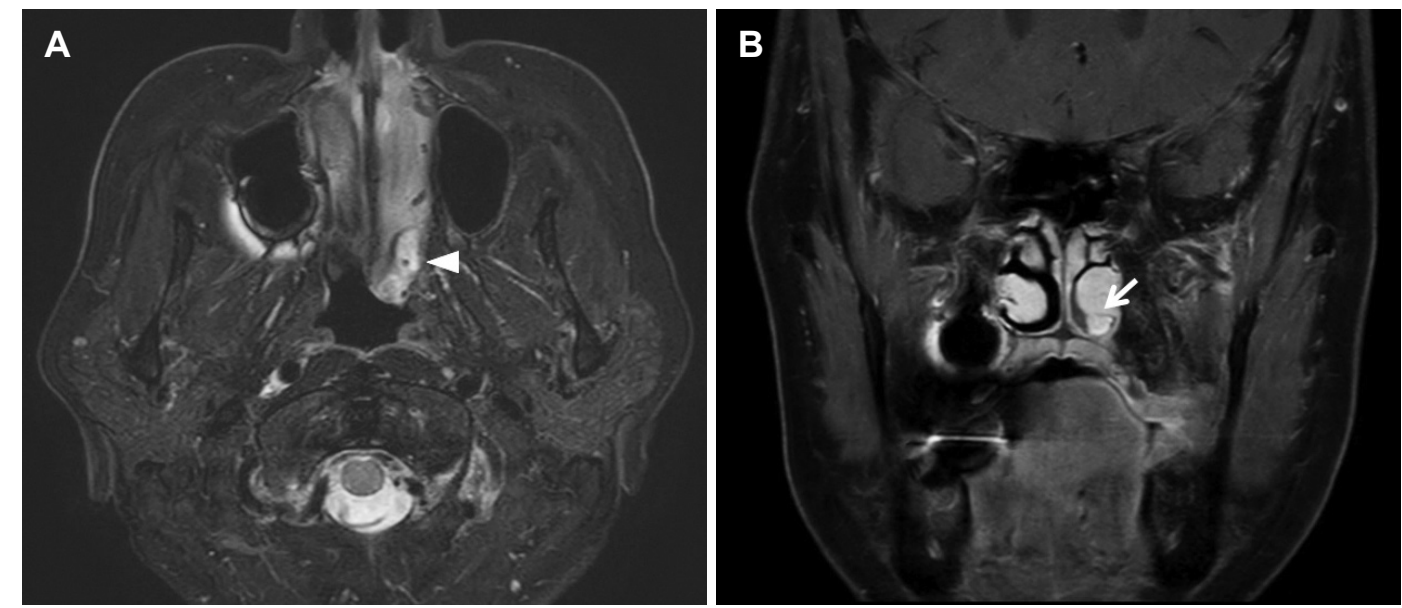

Fig. 3. Preoperative MRI findings. Axial (A) and coronal (B) view. An ovoid homogenous enhancing mass (arrowhead) appears to originate from the posterior inferior side of the left inferior turbinate (arrow) and extends to the choana. 
$0.8 \mathrm{~cm}$ 이었으며 조직 병리 검사 결과는 점막하층의 부종과 호산구 및 형질세포의 침윤이 관찰되는 염증성 비용으로 최 종 진단되었다(Fig. 5).

환자는 수술 후 다음날 퇴원하였고, 호소하던 좌측 코막힘 과 화농성 분비물 증상은 호전되었다. 수술 후 7 개월간 외래 경과 관찰을 하였으나 수술 부위의 점막은 정상으로 회복되 었으며 합병증과 재발의 소견은 관찰되지 않아 치료를 종결 하였다(Fig. 6).

\section{고 찰}

비용(nasal polyp)은 비부비동의 점막이 국소적으로 돌출 하며 나타나는 양성 병변으로, 국내에서는 $2.5 \%$ 의 유병률을 보인다. ${ }^{8)}$ 후비공 비용은 비부비동 점막에서 발생하여 후비공 까지 진행하는 비용으로 소아에서 발생하는 비용 중 $33 \%$ 의 비율을 차지하지만, 성인에서는 4 6\% 정도로 드물게 발생한 다. ${ }^{2,49}$ 특히, 하비갑개에서 기시하는 후비공 비용의 경우는

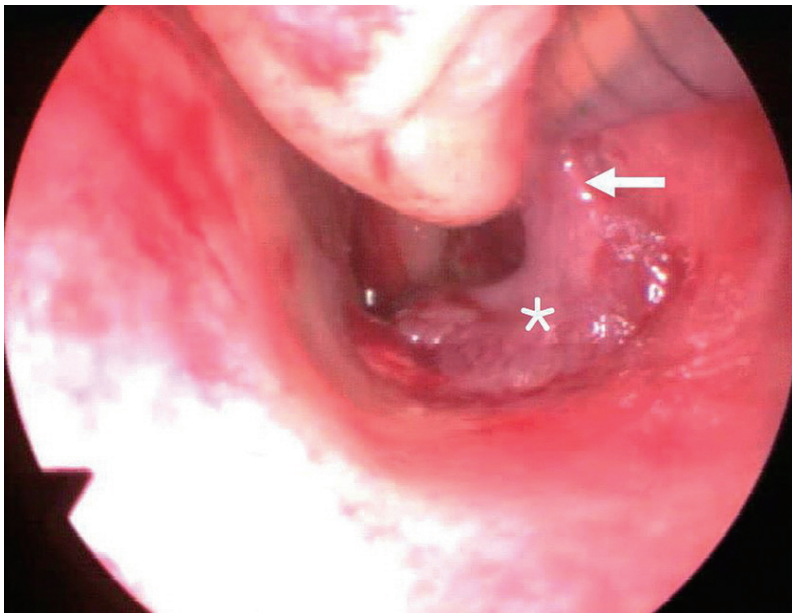

Fig. 4. Operative findings. A pedicle (arrow) of single polypoid mass $\left({ }^{*}\right)$ is attached to the posterior side of the inferior turbinate.
매우 드물게 보고되는데, 현재까지 검색되는 문헌으로는 6예 만이 보고되었으며, 2,4-7) 98 명의 후비공 비용 환자에 대한 Kizil 등 ${ }^{2}$ 의 연구에서는 후비공 비용의 $1 \%$ 만이 하비갑개에 서 기시하는 것으로 보고하였다.

후비공 비용은 비내시경 검사에서 비강을 채우고 후비공까 지 진행하는 비용 형태의 소견을 보이며, 영상의학적 검사는 비용의 기시부와 범위를 파악하고 감별 진단을 하는 데 도움 이 된다. CT 영상에서 후비공 비용은 본 증례와 같이 비부비 동에서 후비공까지 진행하는 저음영의 단일성 종물로 보이 며, ${ }^{10)} \mathrm{MRI}$ 영상에서는 T1 강조영상에서 저신호강도, T2 강조 영상에서 고신호강도 신호를 보여 악성 종양을 비롯한 비강 에서 발생할 수 있는 단일성 질환의 감별에 도움이 된다. ${ }^{2)}$ 후 비공 비용이 하비갑개에서 발생하는 경우는 매우 드물기 때 문에 감별 진단으로 반드시 반전성 유두종(inverted papillo-



Fig. 6. Postoperative endoscopic findings. The mucosa of surgical site was recovered healthy. S: septum.
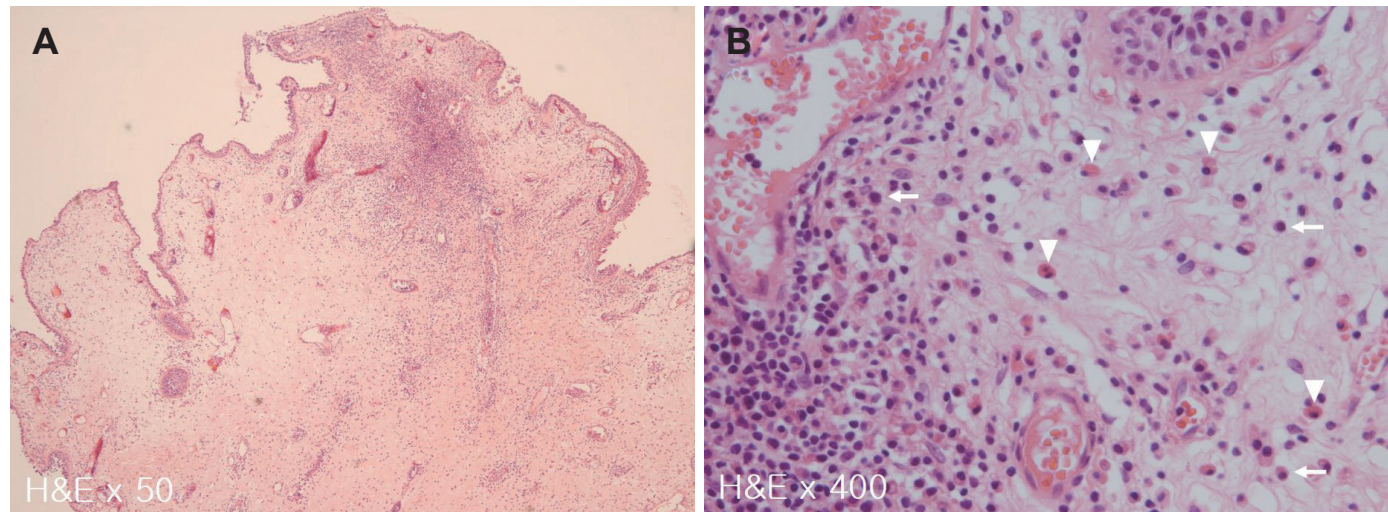

Fig. 5. Postoperative histopathologic findings. Edematous stroma and inflammatory cell infiltration are shown under the epithelium (H\&E, $\times 50)(A)$. Plasma cells (arrows) and eosinophils (arrowheads) are shown (H\&E, $\times 400)(B)$. H\&E: Hematoxylin and eosin. 
$\mathrm{ma})$ 을 고려해야 하며, ${ }^{4,6)}$ 그 외에도 비부비동염에 동반된 비 용, 점액낭종(mucocele), 혈관섬유종(angiofibroma), 혈관종 (hemangioma) 등 편측성 비부비동 내에서 종양으로 나타날 수 있는 질환들을 감별해야 한다. ${ }^{2,6)}$ 본 증례는 비내시경 및 영상검사에서 좌측 하비도의 후방에서 후비공까지 진행되는 종물이 확인되었지만, 종물의 경계가 지저분하고 종물의 발생 지점이 일반적이지 않아 처음에 후비공 비용을 고려하지 못하 였다.

조직병리학적으로 후비공 비용과 다른 비용의 차이를 감별 하기 위한 연구가 있었지만, 후비공 비용의 조직병리학적 소견 은 일반적인 비용과 구분되지는 않았으며 ${ }^{4,9,11)}$ 점막하 조직의 부종에 동반된 다양한 염증세포의 침윤을 보였다.1,10,12) $\mathrm{Min}$ 등 $^{13)}$ 의 연구에서 알레르기 비용과 비교하였을 때 상악동 후비 공 비용의 조직에서는 점액선이 적게 분포하고 호산구 침윤이 적은 조직소견을 보인 반면, Cook 등 ${ }^{11)}$ 의 연구에서는 상악동 후비공 비용 조직에서 점액선 증가와 함께 호산구 및 형질세 포가 증가한 소견을 보였고, 이는 본 증례와 유사한 소견을 보 였다.

지금까지 알려진 후비공 비용의 원인은 비부비동염이 치유 되는 과정에서 점막하샘(submucosal gland)의 폐쇄 및 파열 로 인하여 발생한 점액낭종(mucocele)이 팽창하면서 발생한 다고 보고되었다. ${ }^{12)}$ 그 밖에도 후비공 비용의 발생은 자연공 폐쇄, 비부비동 내의 층류(turbulent air flow)와 같은 물리적 인 요인 ${ }^{14}$ 과 알레르기 유무가 언급되었다. ${ }^{11,12,14)}$ 본 증례의 경우 다수의 호산구가 관찰되는 조직학적 소견을 고려하였을 때, 하비갑개에서 기시한 후비공 비용의 발생에 알레르기 반응이 관련이 있을 것으로 생각된다. 하지만 하비갑개에서 기시하는 후비공 비용이 흔하지 않고 이에 대한 구체적인 기전이 연구되 지 않아 앞으로 이에 대한 연구가 필요할 것으로 생각된다.

후비공 비용의 치료는 기시부를 포함한 종물의 완전한 제거 이다. 후비공 비용에 대해서 비용 절제술만을 시행하였을 때 재발하였기 때문에 ${ }^{2,5,6)}$ 기시부를 포함하여 종물을 완전히 절 제해야 한다. 비내시경을 통한 절제 후 상악동 후비공 비용의 재발율은 $4.3 \%$ 에서 $21.1 \%$ 까지 보고되었고, ${ }^{2}$ 하비갑개에서 기 시한 후비공비용의 경우 여섯 증례 중 한 증례에서만 재발하 였다. ${ }^{4}$ 따라서 후비공 비용을 수술할 때에는 기시부의 확인과 기시부를 포함한 주변부의 완전한 절제가 필요하며 수술 후에 도 주기적인 경과 관찰이 필요하다.

최근 $\operatorname{Min}$ 등 $^{15)}$ 은 65 세 남자 환자에서 우측 하비갑개 전방 에서 발생한 $1.4 \times 0.8 \mathrm{~cm}$ 크기의 단일의 염증성 비용(inflammatory polyp)에 대한 증례를 보고하였다. 본 증례와 달리 병변 위치의 차이가 있었지만, 고령의 환자에서 하비갑개에 발생한 작은 크기의 단일 비용으로 인해 단기간에 코막힘을
호소한 공통적인 임상 양상을 보였다. 이는 소아 및 청소년기 에 흔하게 발생하고, 상대적으로 크기가 큰 후비공 비용의 임상양상과는 차이를 보였다. 따라서 본 증례를 통해 코막힘 을 호소하는 고령의 환자가 하비갑개에서 기원하여 후비공까 지 진행하는 종물이 관찰되는 경우에는 후비공 비용의 가능 성을 고려해 볼 수 있을 것으로 생각된다.

\section{Acknowledgments}

None.

\section{Author Contribution}

Conceptualization: Sang Hyeon Ahn, Ju Chang Kang. Data curation: Ju Chang Kang, Kyu Ha Shin, Kye Won Kwon. Formal analysis: Han Kyung Sung. Visualization: Kye Won Kwon. Writing - original draft: Ju Chang Kang. Writing - review \& editing: Kyu Ha Shin, Kye Won Kwon, Sang Hyeon Ahn.

\section{ORCID}

Sang Hyeon Ahn https://orcid.org/0000-0002-2389-0005

\section{REFERENCES}

1) Lopatin A, Bykova V, Piskunov G. Choanal polyps: One entity, one surgical approach? Rhinology 1997;35(2):79-83.

2) Kizil Y, Aydil U, Ceylan A, Uslu S, Baştürk V, İleri F. Analysis of choanal polyps. J Craniofac Surg 2014;25(3):1082-4.

3) Erkan AN, Cakmak O, Bal N. Frontochoanal polyp: Case report. Ear Nose Throat J 2009;88(5):E1.

4) Gordts F, Clement PA. Unusual choanal polyps. Acta Otorhinolaryngol Belg 1997;51(3):177-80.

5) Yariktaş M, Doğru H, Döner F, Tüz M, Yasan H. Choanal polyp originating from the inferior turbinate presenting as nasal polyposis. Kulak Burun Bogaz Ihtis Derg 2006;16(1):37-40.

6) Aydil U, Karadeniz H, Sahin C. Choanal polyp originated from the inferior nasal concha. Eur Arch Otorhinolaryngol 2008;265(4):477-9.

7) Adhami M, Coste A, Escabasse V, Chalumeau F. The inferior turbinate, an unusual site for a choanal polyp: Two case reports and a review of the literature. Ear Nose Throat J 2016;95(7):E1-4.

8) We J, Lee WH, Tan KL, Wee JH, Rhee CS, Lee CH, et al. Prevalence of nasal polyps and its risk factors: Korean National Health and Nutrition Examination Survey 2009-2011. Am J Rhinol Allergy 2015; 29(1):e24-8.

9) Hong SK, Yoo YS, Shin YR, Chung SW. Choanal polyps originating from the ethmoid sinus: Ethmochoanal polyps? Korean J Otolaryngol 2002;45(9):921-5.

10) Dadaş B, Yilmaz O, Vural C, Caliş AB, Turgut S. Choanal polyp of sphenoidal origin. Eur Arch Otorhinolaryngol 2000;257(7):379-81.

11) Cook PR, Davis WE, McDonald R, McKinsey JP. Antrochoanal polyposis: A review of 33 cases. Ear Nose Throat J 1993;72(6):401-2, 404-10.

12) Ozdek A, Samim E, Bayiz U, Meral I, Safak MA, Oğuz H. Antrochoanal polyps in children. Int J Pediatr Otorhinolaryngol 2002;65(3):213-8

13) Min YG, Chung JW, Shin JS, Chi JG. Histologic structure of antrochoanal polyps. Acta Otolaryngol 1995;115(4):543-7.

14) Ertugrul S, Ensari S. Choanal polyp originating from superior turbinate. Int J Res Med Sci 2017;5(9):4158-60.

15) Min HJ, Kim KS. Inflammatory polyp arising from the inferior turbinate. Ear Nose Throat J 2020;99(6):NP66-7. 